Historic, Archive Document

Do not assume content reflects current scientific knowledge, policies, or practices. 

Forest production in the Northeast can be increased materially by reducing. insect-caused losses. Alertness in recognizing and reporting insect damage is the key to an effective control program. Better coordination of surveys, more uniformity and improvement in survey techniques, and more frequent interchange of information are needed to develop an efficient regional program. The Northeastern Forest Experiment Station stands ready to actively assist in attaining these objectives.

This report is the product of survey activities and findings in all states in the region during 1955. Acknowledgment is made to the many persons and agencies who contributed to it. 
INTRODUCTION . . . . . . . . . . . . . . 1

MAJOR FOREST INSECT PESTS

Spruce budworm .. . . . . . . . . 2

Pine sawflies . . . . . . . . . . . 4

Pine looper . . . . . . . . . . . 5

Matsucoccus scale . . . . . . . . . 6

Balsam woolly aphid . . . . . . . . . 6

Forest tent caterpillar . . . . . . . 6

Gypsy moth . . . . . . . . . . . . 7

Beech scale . . . . . . . . . . 8

Saddled prominent . . . . . . . . . 9

SURVEY AND CONTROL PLANS FOR 1956 . . . . . 9

FOREST INSECT SITUATION: TABULATED SUMMARY . • 11 


\section{.}




\title{
Forest Insect Conditions
}

\section{In The Northeast - 1955}

\author{
by \\ W. E. Waters 1 \\ Forest Entomologist \\ Northeastern Forest Experiment Station \\ Forest Service, U.S. Dept. Agriculture
}

\section{NTRODUCTION}

THE TREMENDOUS DESTRUCTIVE capacity of forest insects in reducing our resources of usable timber is becoming increasingly apparent as the shoe of the forest economy pinches tighter. The U. S. Forest Service's recent TIMBER RESOURCE REVIEW, which presents the findings of the most comprehensive survey to date of the present and future timber supply of the United States and coastal Alaska, gives a graphic picture of their importance. For example, forest insects killed more trees in 1952 than any other agent. The growth impact (tree mortality plus growth loss) by insects alone amounted to 16 percent of the total on growing stock and 20 percent of that on sawtimber. In the Northeast, outright tree mortality is relatively less important than in other regions, but the loss in growth and merchantable volume is considerable.

Forest insect conditions in the Northeast in 1955 were characterized by a decrease in the area and/or severity

\footnotetext{
${ }_{1}$ A member of the Experiment Station's Division of Forest Insect Research, stationed at the Forest Insect and Disease Laboratory, New Haven, Conn.
} 
of attack by certain major pests and increased damage by insects that usually are less important.

Forest tent caterpillar infestations in New York, Vermont, and New Hampshire seemed to be definitely on the decline. The gypsy moth defoliated only 52,061 acres this year, as compared with 491,448 acres in 1954 and 1,487,077 acres in 1953. A high incidence of wilt disease, parasites, and predators aided considerably in disposing of the gypsy moth in untreated areas within the generally infested portion of New England. Spruce budworm populations in New York, Vermont, and New Hampshire were negligible; and only light defoliation was observed in one area of northeastern Maine. However, the outlook for the gypsy moth and the budworm in 1956 is not particularly encouraging. Scouting and trap catches indicate a southward and westward spread of the gypsy moth (since 1953) into southern New York, northern New Jersey, and northeastern Pennsylvania. Gypsy moths have been observed west of the Adirondack barrier zone, too. A large influx of budworm moths covered a wide area in northeastern Maine; and light to medium populations are expected in areas that up to now have not been infested.

Pine sawflies, the saddled prominent, and the pine looper assumed serious proportions in 1955. Control operations were conducted against these pests, and further measures may be called for in 1956. The beech scale and the associated Nectria fungus are now established at a number of points in central Vermont, presenting a new threat to the beech stands there.

Other major pests--the white-pine weevil, the balsam woolly aphid, the red pine (Matsucoccus) scale, and the European pine shoot moth--continued active at damaging levels.

\section{MA JOR FOREST INSECT PESTS}

Spruce

budworm

Spruce budworm populations in Maine were at a low level in 1955. Defoliation, where present, was generally light. The most noticeable defoliation, defined by extensive aerial and ground surveys by state and federal personnel, was in the northeastern townships in the vicinity of T16R4 and Stockholm.

Later in the season, observations by men in the field and moth catches in light traps indicated a considerable in- 
flux of budworm moths into northern Maine, including the Madawaska Lake spray area. Considerable numbers of budworm. moths were seen and collected in the Presque Isle - Squapan Lake area. The unusual moth activity was noted mostly on the nights of July 11 and 12 and July 18 to 22. As recorded by the U. S. Weather Bureau at Caribou and the regional Weather Forecast Center in Boston, a cold front oriented in a northeast-southwest direction moved into Maine from the north on July 10. Another cold front, similarly oriented, moved in from Canada on the 18th. Considering the close proximity (less than 5 miles at one point) of the heavy infestations in New Brunswick and Quebec to the fir stands in northeastern Maine, it is quite probable that these moths were carried by the two weather fronts reported above. It is rather remarkable that the phenomenon has not occurred befcre and, in fact, regularly. Such weather fronts are not uncommon in this region during July.

The egg-mass survey, which covered 190 points in northern Maine, showed that egg masses were-deposited in many areas where little or no deposition was expected--and many more egg masses than anticipated in other areas. Therefore light to medium defoliation is expected over a larger area in northern Maine in 1956.

Budworm populations in New Hampshire, Vermont, and New York remained at a very low level in 1955. Defoliation was negligible in those states.

In Quebec and New Brunswick, the budworm outbreak continues as a serious threat. The moderate to severe infestations in New Brunswick, including the sprayed areas, covered about 13,000 square miles. The main outbreak is still confined mostly to the northern part of the Province, with only slight extensions to the southward in 1955. However, egg-mass-survey findings indicate a probable further extension southward in 1956. The most severe areas of infestation in Quebec are in the lower St. Lawrence and Gaspé regions. Elsewhere in the Province a few centers of heavy infestation still persist; and in the St. Maurice and Jacques Cartier regions, balsam fir continues to die at an increasing rate.

Combined aerial-spraying operations in New Brunswick and Quebec covered 2,200,000 acres, the largest annual operation to date. The results are considered generally satisfactory, as good protection was afforded the current growth. Studies of the areas in New Brunswick that were sprayed previously (standard dosage of $1 / 2$ pound DDT in $1 / 2$ gallon of oil solution per acre) indicate that the protection has been effective, but temporary. Heavy populations are recurring 
in stands that initially showed good recovery after treatment. It is considered probable that continued protection will require respraying at about 3-year intervals until the crop is harvested or the outbreak subsides.

Pine

sawflies

Sawflies, particularly those that infest planted pines, are a perennial problem in the Northeast. Applied control of certain of these gregarious defoliators has become an annual task in some states--the red-headed pine sawfly (Neodiprion lecontei) in New York and the European pine sawfly (N. sertifer) in New Jersey, for example. Natural stands of pine may come under attack too. Extensive areas of loblolly and Virginia pine in Maryland have been seriously infested for several years. The most important sawflies and their main areas of activity in 1955 are listed below.

Red-headed pine sawfly.--Most prevalent in New York. In St. Lawrence County 950 acres were sprayed with DDT (6 percent) by airplane.

European pine sawfly.--A major pest in northern New Jersey. Airplane spraying has been conducted for over 5 years to control this insect in state and private plantings of red pine. Although no spraying was carried out in 1955, operations are planned to continue spraying in 1956. Spot infestations have caused serious damage to red pines throughout southeastern Connectjcut for several years. In 1955, over 100 acres of a reservoir planting near Stamford were severely defoliated.

A spray containing a pathogenic virus of this insect has been found to be very effective for control. This method of control is relatively inexpensive, because a concentrated suspension of the virus polyhedra can be obtained easily by placing diseased larvae in water and allowing them to disintegrate. For application, this suspension is diluted to the proper concentration by the addition of water. Establishment of the disease in an area is assurance of a source of supply of the virus and a continuing control effect.

Neodiprion taedae taedae.--Now active on the Eastern Shore of Maryland. Severe defoliation of loblolly pine has occurred at various localities there since 1952. Populations of the insect are now apparently on the decrease. The defoliation in 1955 was generally light to moderate and was restricted mostly to stands along the larger waterways. 
Neodiprion pratti pratti.--Currently attacking Virginia pine and other pines over a wide area in central Maryland. An aerial survey in May revealed infestations up to 1,500 acres in 6 counties. Defoliation was most severe on Virginia pine, with the heaviest feeding observed in the Patuxent River drainage and in a small area near Fenwick.

Pine

looper

This insect, which is closely related to the hemlock looper, has a well-documented history of outbreaks on Cape Cod, Mass. It has recurred there at approximately 10-year intervals since 1913 (and possibly earlier). Its primary host in the Cape area is pitch pine, although it may feed on other conifers and even on scrub aak when in mixture with pitch pine and the food supply is low. In Connecticut this pest periodically infests red pine.

A severe outbreak on the Cape, first noticed in 1953, has caused considerable damage and much concern there. Scenic as well as timber values are involved. In 1954, light to heavy defoliation occurred in all towns on the Cape; and several large areas were almost completely stripped. Defoliation in 1955 was generally lighter, although still widespread.

By special action of the Massachusetts Legislature, $\$ 100,000$ was made available this year to combat the pest. Operations were begun on July 18 and were completed August 6. A 9-percent DDT oil solution was applied at the rate of $2 / 3$ gallon per acre. A total of 203,074 acres were treated under a state contract, covering all areas on the Cape where considerable pitch pine was present. An additional 19,934 acres were sprayed in three separate United States Army installations. Satisfactory protection was not obtained in many areas.

Approximately 300 acres of red pine surrounding a reservoir in North Branford, Conn., were heavily infested by this looper in 1954 and 1955. Some tree mortality has resulted, with heaviest losses on a 65-acre island in the center of the lake. On July 29, 200 acres were sprayed by helicopter. A 12-percent DDT oil solution was applied at the rate of 1 gallon per acre. Excellent control was effected: very few surviving larvae were found in a subsequent examination of the area. 
Matsucoccus

scale

A survey of the present distribution of this scale on red pine in Connecticut has revealed an extension of only $1 / 2$ to 2 miles beyond the 1953 limits. The most consistent spread has been in an easterly and northeasterly direction. It now covers an area of approximately 90 square miles in Fairfield County. Undetected small infestations may well occur, however, beyond the limits now specified.

No increase was reported of the spot infestations in southeastern New York or of those on Long Island. A number of red pine plantings in northeastern New Jersey, some only several air miles from infested points in New York, were inspected closely in 1955. Branch samples were taken at each check location for laboratory examination. No evidence of Matsucoccus was found.

This insect, a definite threat to the extensive plantings of red pine in the Northeast, has been technically described as a new species, M. resinosae B. and G. Although host-specificity tests prior to 1955 had indicated that it could exist only on red pine, comparatively large numbers were found on Japanese red pine (Pinus densiflora) and on a Chinese pine ( $\mathrm{P}$. tabulaeformis) at the Boyce Thompson Institute arboretum in Yonkers, New York. It is not known as yet whether the insect has overwintered on these new hosts.

\section{Balsam}

woolly aphid

This insect recurs annually to cause considerable loss of balsam fir in Maine, New Hampshire, and Vermont. Continued tree mortality was reported over a wide area in each of those states in 1955. Infestations in New York were less severe. Valuable stands in the Green Mountain and White Mountain National Forests were severely infested, although damage in the latter was reported decreasing. However, examination of study plots in both national forests indicated that further tree mortality can be expected.

Forest

tent caterpillar

The current outbreak of this destructive pest in New York and northern New England appears to be on the downgrade.

In New York, 6,276,700 acres of defoliation were mapped from the air, as compared with over 15,000,000 acres in 1954. Nearly all (6,262,000 acres) of the 1955 defoliation 
was light; only 6,400 acres were recorded as medium and 8,300 acres as heavy. Five small areas of special interest, totalling 135 acres, were sprayed this year; over 6,400 acres were treated in 1954. A further decline in infestations is predicted for 1956.

In Vermont, only light and scattered defoliation was observed this year. Approximately 1,960 acres were sprayed at the rate of $1 / 2$ pound of DDT per acre to protect sugar orchards that had suffered 1 or more severe defoliations. Little or no attack is expected in 1956.

Infestation by this insect in New Hampshire was very light and scattered. In Maine, also, only a small number of spot infestations were reported. These were limited in both intensity and area.

Gyps $y^{2}$

moth

Infestations within the generally infested region of New England declined sharply in 1955--for the second successive year. This was due largely to a high incidence of disease, parasites, and predators, augmented by large-scale spraying programs. In the spring of 1955, DDT spray was applied to 1,108,298 acres of open growth and woodland by cooperating federal, state, and local agencies and organized groups of property owners. In untreated areas with high gypsy moth populations, there was a heavy mortality of late instar larvae and pupae by the wilt disease and the parasite Sturmia scutellata. The extent of defoliation decreased correspondingly. A survey revealed only 52,061 acres defoliated, in contrast to 491,448 acres in 1954 and the alltime peak of $1,487,077$ acres in 1953.

Although this year's defoliation survey showed a greatly reduced area affected in the generally infested region, a slight increase in defoliation was noted on the periphery. This indicates that active populations of the insect still exist in the fringe areas, particularly in eastern New York, southwestern Connecticut, and Vermont.

Moreover, a considerable build-up of infestation is indicated in areas immediately south and west of the presently regulated area. Surveys west of the Hudson River in southeastern New York, northern New Jersey, and northeastern

\footnotetext{
${ }^{2}$ Information and data supplied by the Gypsy and Brown-tail Moth Control Project, Pest Control Branch, Agricultural Research Service, U.S. Department of Agriculture.
} 
Pennsylvania showed that considerable dispersal of the gypsy moth into these areas had occurred during and since the peak of the outbreak in 1953. The 1955 trap catches and scouting reports indicate that approximately $8-3 / 4$ million acres are involved.

Table 1.-- Summary of gypsy moth spraying in 1955 (fiscal year)

\begin{tabular}{|c|c|c|c|c|c|}
\hline \multirow{2}{*}{ State } & \multicolumn{2}{|c|}{ With aircraft } & \multicolumn{2}{|c|}{ With mist blower } & \multirow{2}{*}{ Total } \\
\hline & Federal & $\begin{array}{c}\text { State \& } \\
\text { other }\end{array}$ & Federal & $\begin{array}{c}\text { State \& } \\
\text { other }\end{array}$ & \\
\hline & Acres & Acres & Acres & Acres & Acres \\
\hline Connecticut & -- & 11,305 & 2,124 & -- & 13,429 \\
\hline Maine & -- & 13,493 & 500 & 4,600 & 18,593 \\
\hline Massachusetts & -- & 815,631 & -- & - & 815,631 \\
\hline Michigan & -- & 35,970 & -- & -- & 35,970 \\
\hline New Jersey & 640 & -- & -- & -- & 640 \\
\hline New York & 159,554 & 33,805 & 473 & 560 & 194,392 \\
\hline Rhode Island & - & -- & -- & 16,872 & 16,872 \\
\hline Vermont & 4,400 & 8,371 & -- & -- & 12,771 \\
\hline Totals & 164,594 & 918,575 & 3,097 & 22,032 & $1,108,298$ \\
\hline
\end{tabular}

The isolated gypsy moth infestation in the vicinity of Lansing, Mich., appears well under control after extensive spraying operations in 1954 and 1955. Intensive surveys are being continued to detect any infested spots not previously discovered. Table 1 gives a summary of spraying operations conducted cooperatively by the states and the federal government in 1955.

Beech

scale

This bark insect is now present on much of the Green Mountain National Forest in Vermont. Its lethal companion, a Nectria fungus, has been reported from two points 50 miles apart; it may occur elsewhere. At one point, near Granville, limited tree mortality was recorded in 1955. With a record of severe damage to beech in New Hampshire and Maine, which is continuing, this destructive pair now pose a serious threat to the beech stands in Vermont. In the Catskill region of New York no change in the severity or extent of infestation was reported. 
This is another periodically destructive pest, with a record of outbreaks in New England at approximately 10-year intervals since 1907. This year heavy feeding was present over 23,000 acres in western Massachusetts and 3,000 acres in Rensselaer County, New York, adjacent to the Massachusetts state line. Beech and sugar maple were most heavily fed upon; oak and birch were also attacked when in mixture with the preferred hosts. In late July, 2,420 acres of the New York infestation were sprayed with a 12-percent DDT solution by airplane. This operation was conducted by the New York State Conservation Department. Sample pupal collections throughout the infested areas in Massachusetts and New York indicated outbreak numbers again in 1956.

\section{SURVEY AND CONTROL PLANS F O R 1956}

The gypsy moth and the spruce budworm present the major survey problems concerning individual species in 1956. The wide distribution of the gypsy moth in southeastern New York, northern New Jersey, and northeastern Pennsylvania may require new techniques of scouting and sampling populations on the ground. The expected increase in budworm populations in northern Maine will call for continued coordination of larval and egg-mass surveys on the ground and a defoliation survey from the air.

Increased emphasis will be given to surveillance for insects of lesser or more sporadic importance. The known infestations of the forest tent caterpillar, saddled prominent, sawflies, and other species will be investigated. This work will be conducted largely by the individual states. A more intensive survey of the beech scale and Nectria will be conducted in Vermont by the Northeastern Forest Experiment Station. It is hoped that material improvements may be made in the coordination of survey activities and the interchange of information among the states.

Control activities, as now planned, will be largely on a maintenance basis. A reduced spraying program will be directed against the gypsy moth in the generally infested area and in certain fringe areas. No spraying against the spruce budworm is planned for 1956. It is certain that considerable funds will be expended by all states to protect trees in special-use areas, including watershed plantings. A very interesting operation is planned against the European 
pine sawfly in the pine plantations of the Stamford (Conn.) Water Company. A virus spray will be dispersed over several hundred acres by airplane or on a more restricted acreage by mist-blower. 


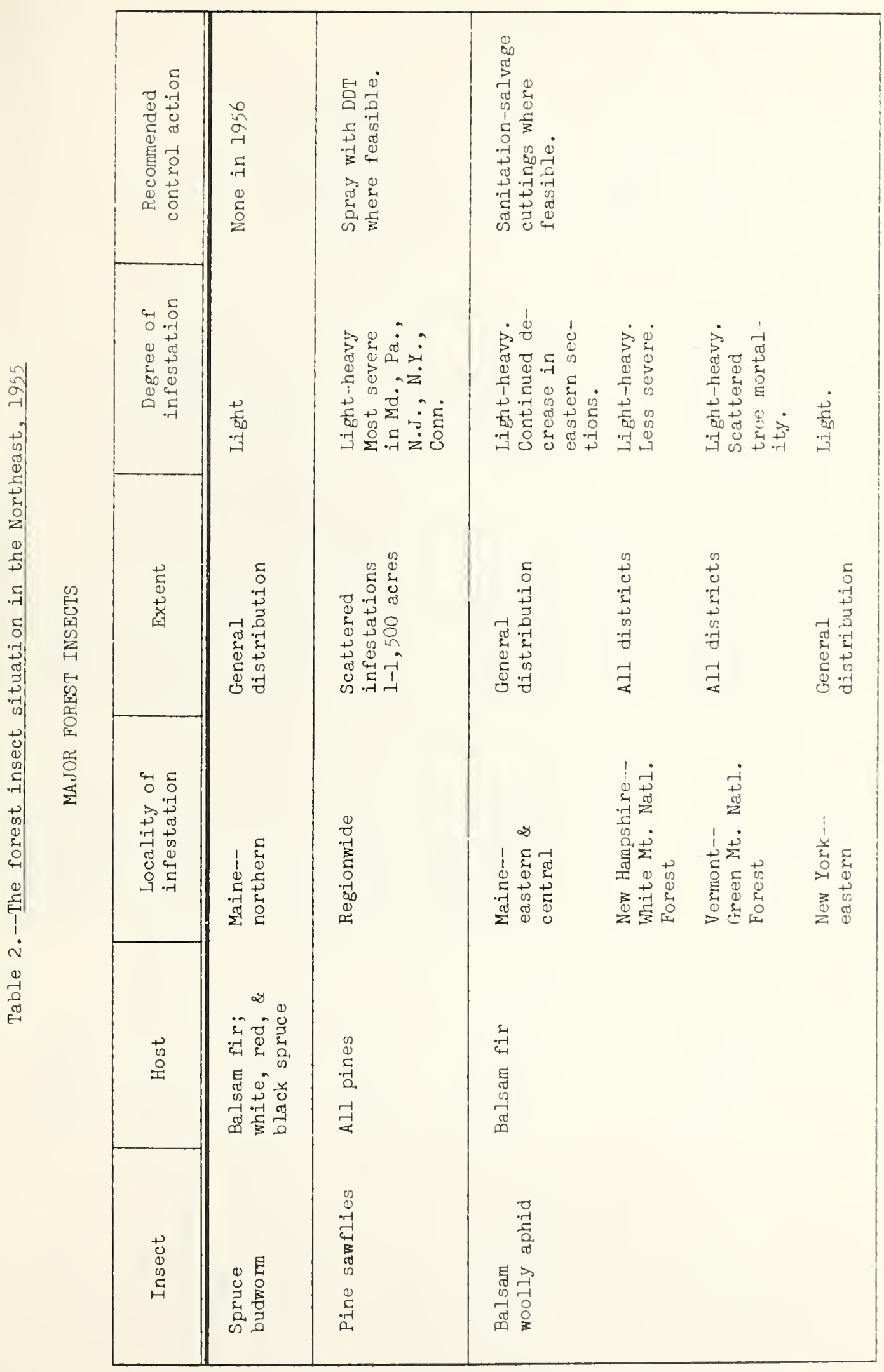




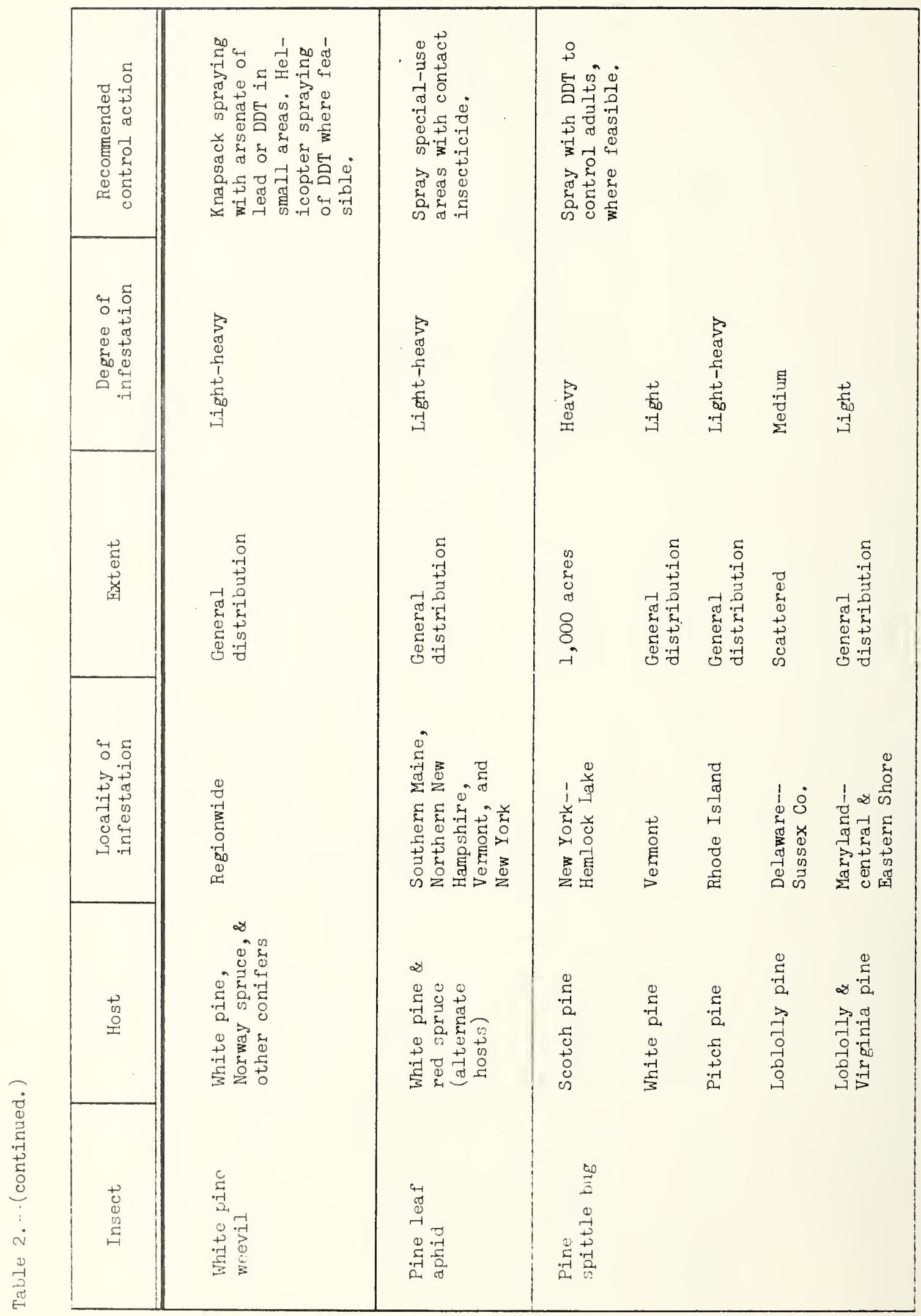




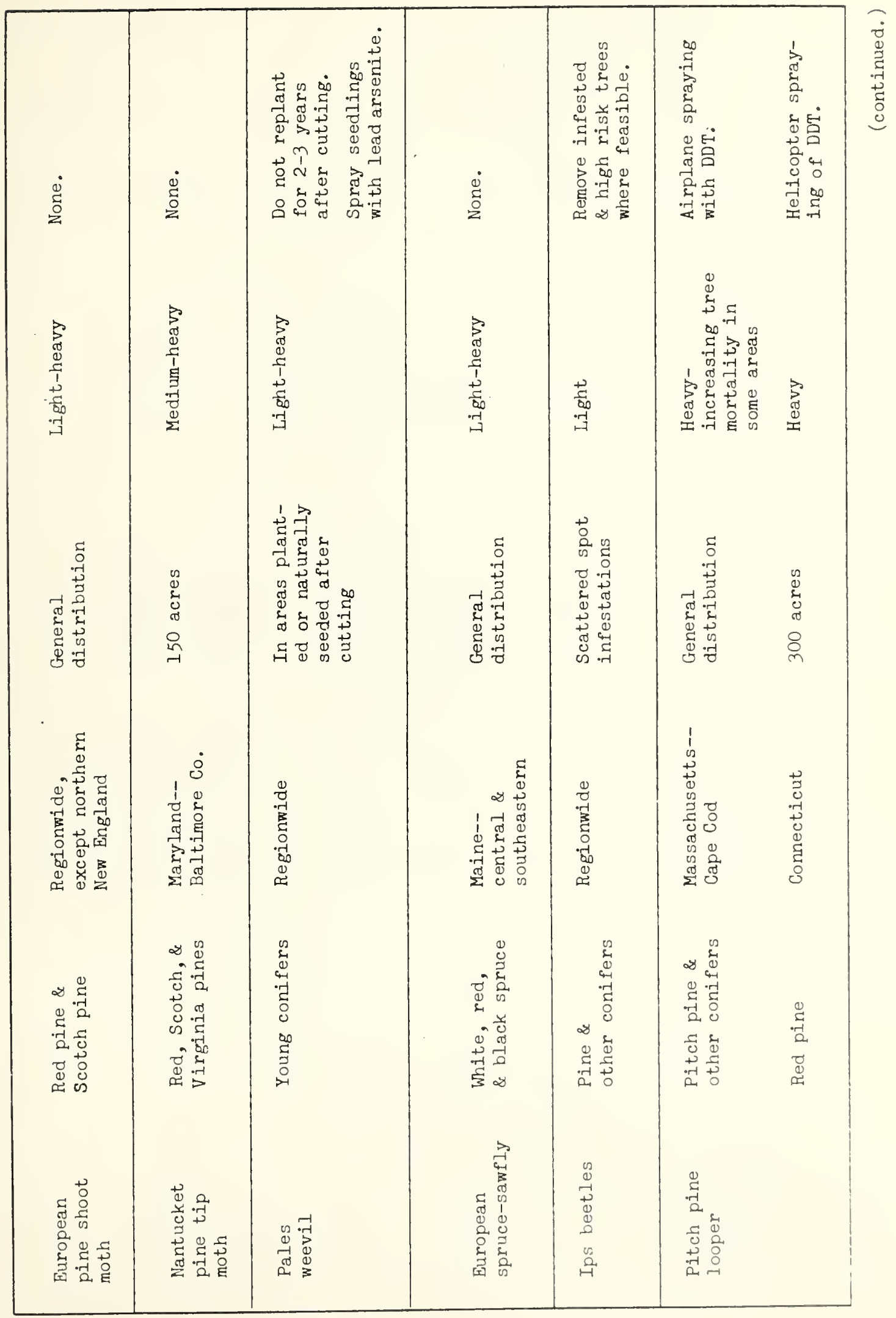




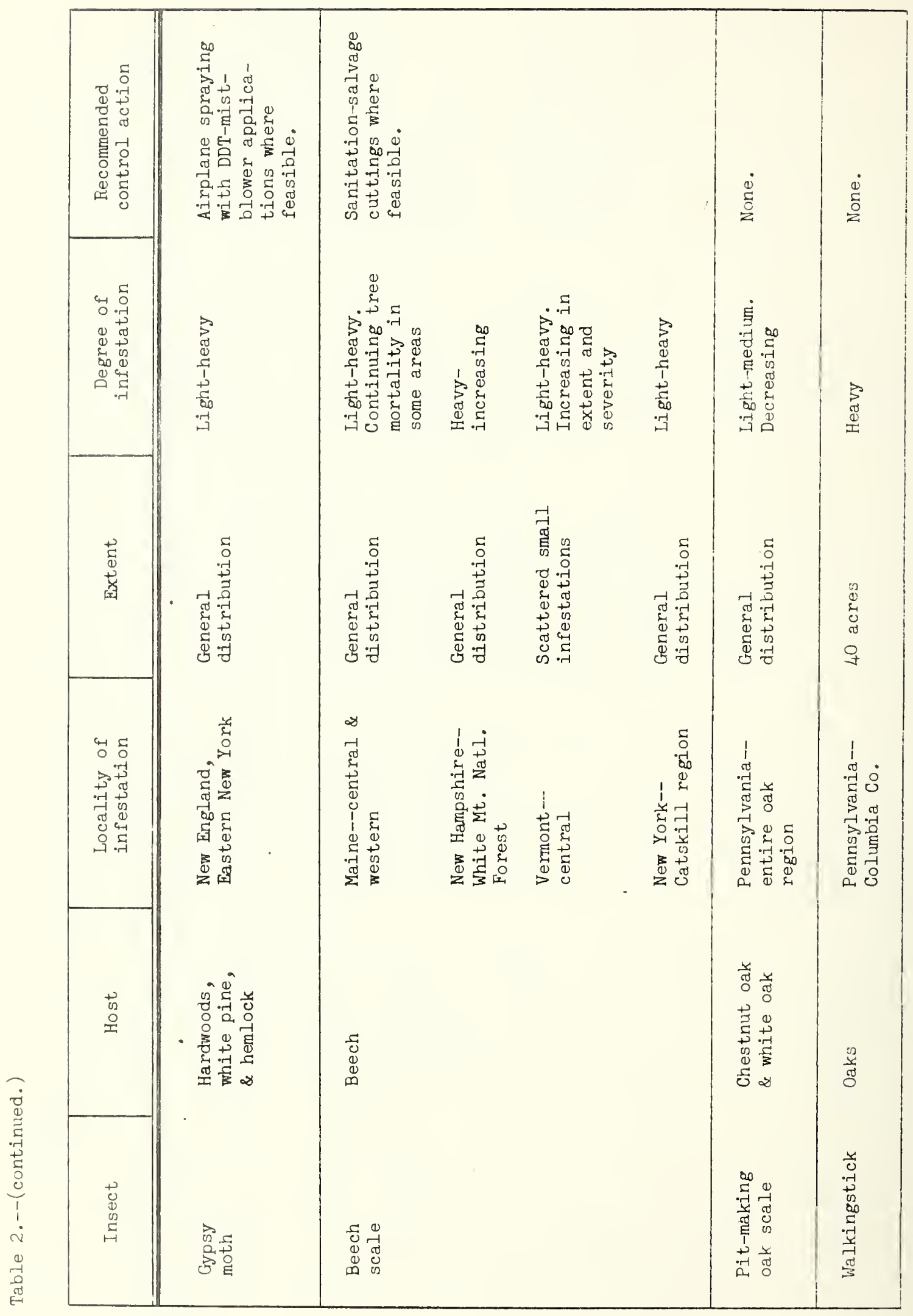




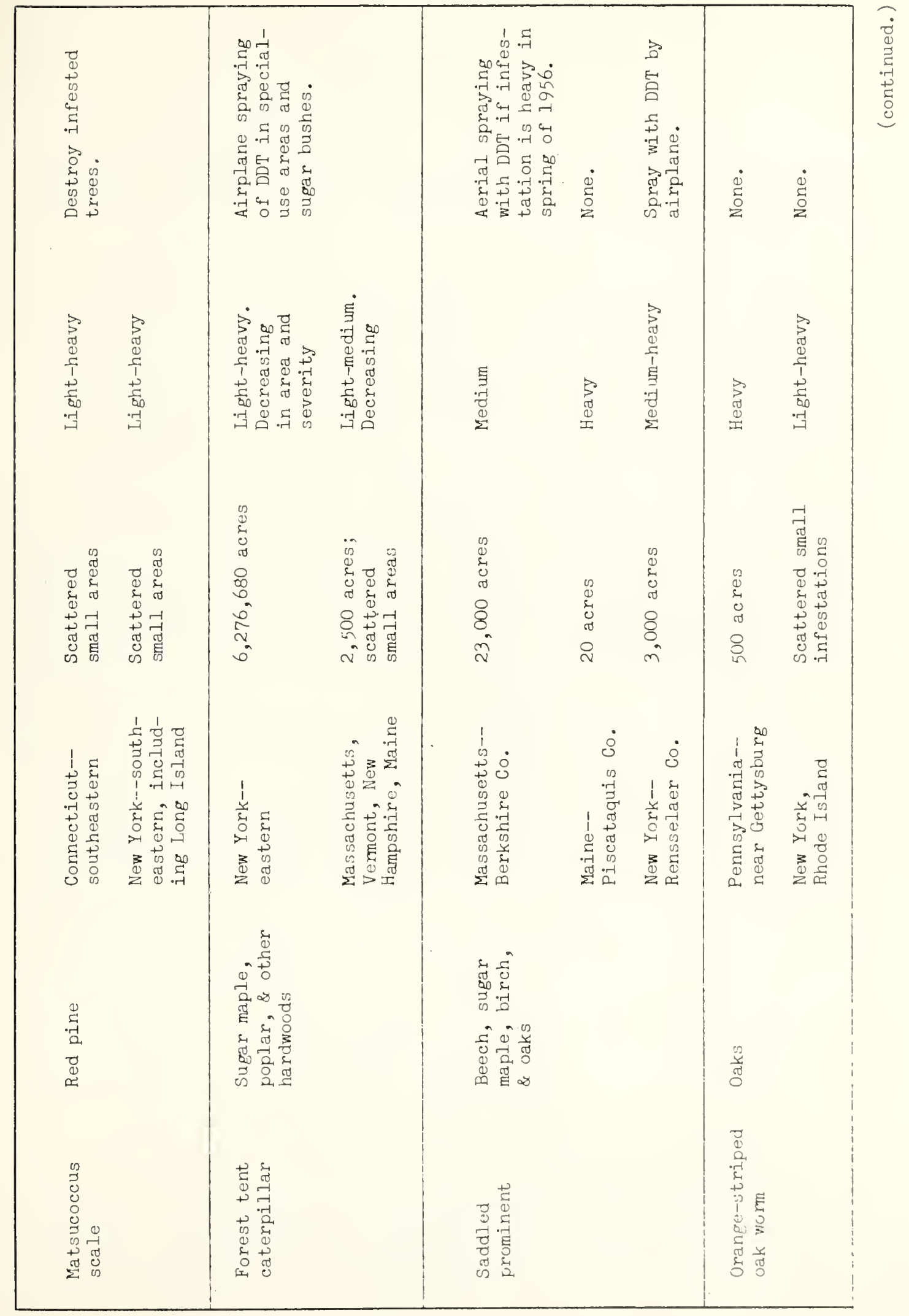




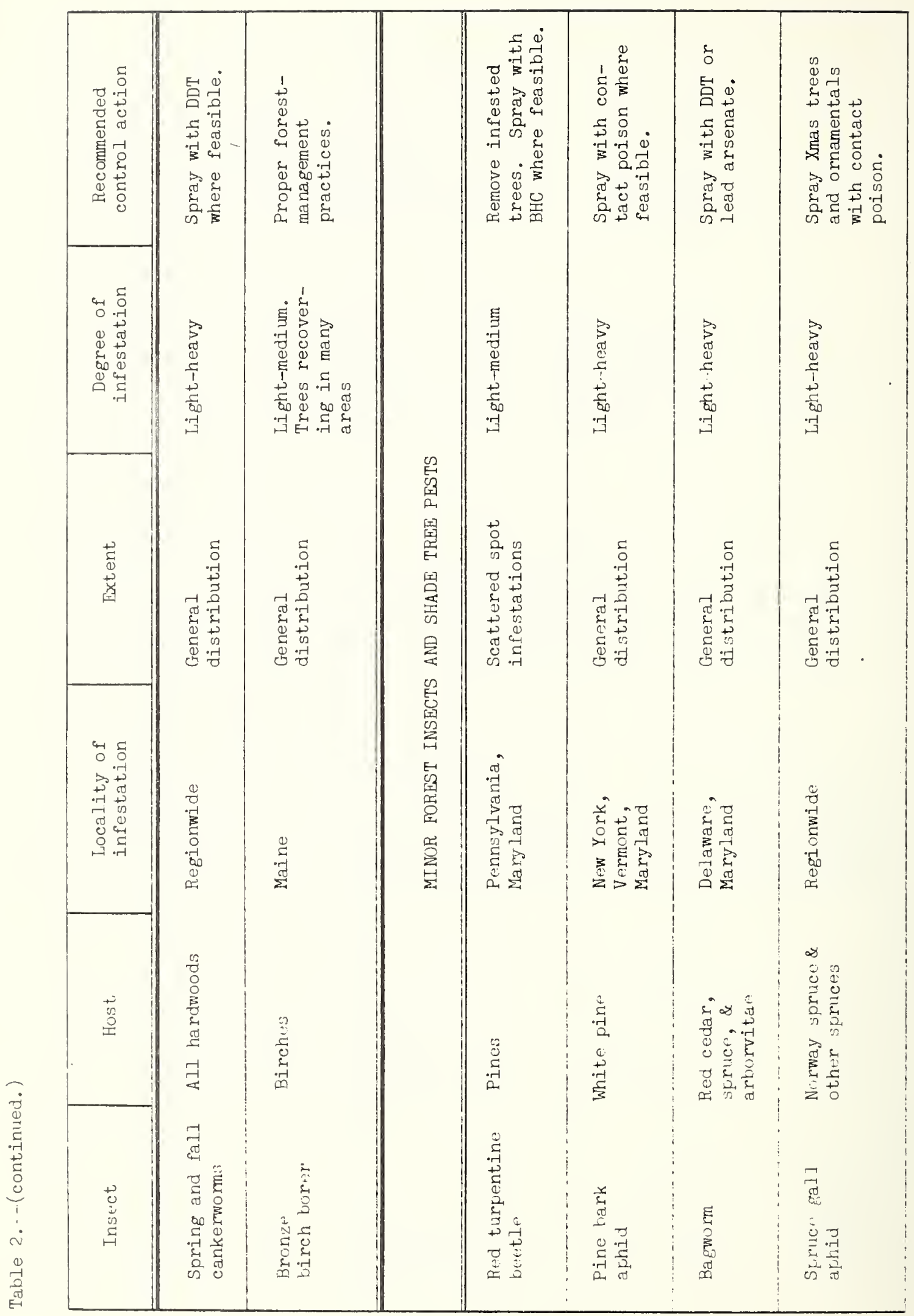




\begin{tabular}{|c|c|c|c|c|c|c|c|c|}
\hline 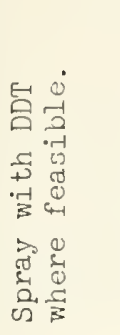 & 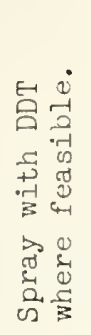 & 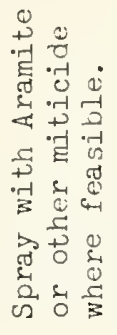 & $\begin{array}{l}\dot{0} \\
\text { Ḋ } \\
\text { 己 }\end{array}$ & 苛 & 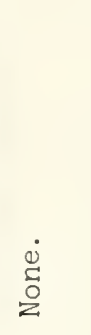 & 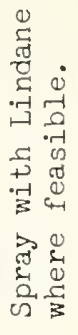 & 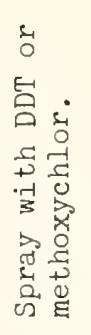 & 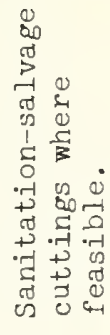 \\
\hline 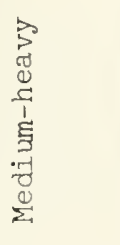 & 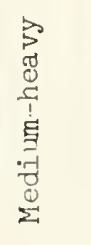 & 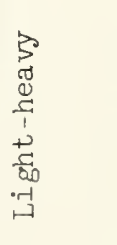 & 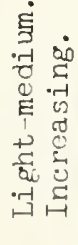 & 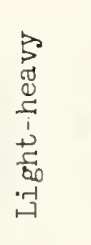 & 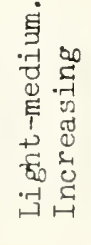 & 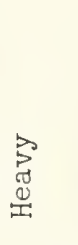 & 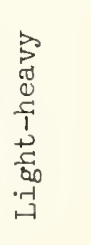 & 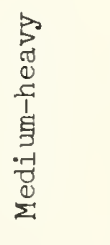 \\
\hline 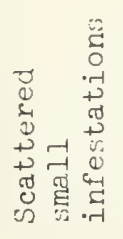 & 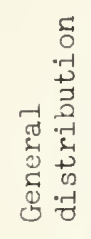 & 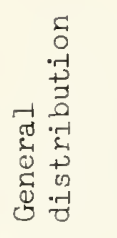 & 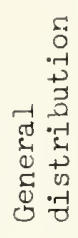 & 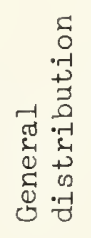 & 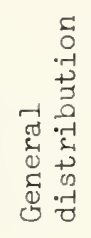 & 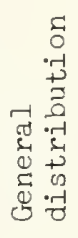 & 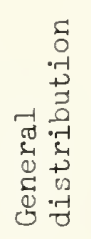 & 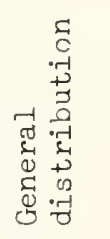 \\
\hline 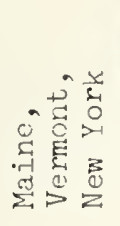 & 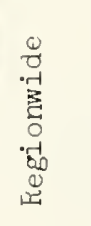 & 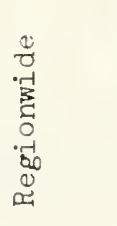 & 离 & $\begin{array}{l}+ \\
0 \\
0 \\
0 \\
0 \\
0\end{array}$ & 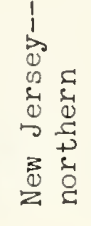 & 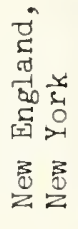 & 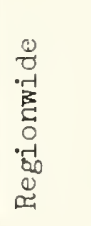 & 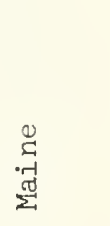 \\
\hline 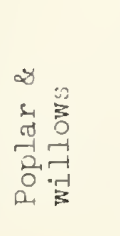 & 舁 & 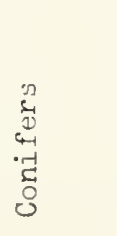 & 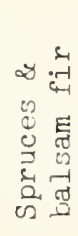 & 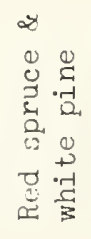 & 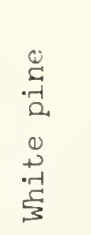 & $\begin{array}{l}0 \\
\stackrel{D}{0} \\
\stackrel{0}{0} \\
\stackrel{-1}{m}\end{array}$ & 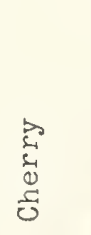 & 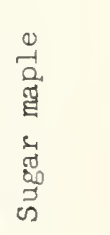 \\
\hline 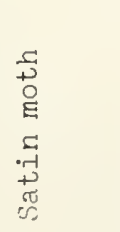 & 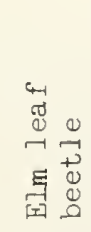 & 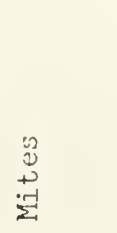 & 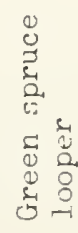 & | & 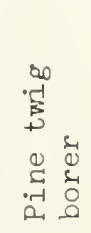 & 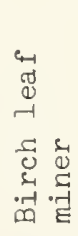 & 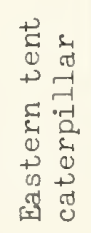 & 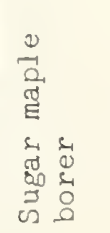 \\
\hline
\end{tabular}




\begin{tabular}{|c|c|c|c|c|c|c|c|}
\hline 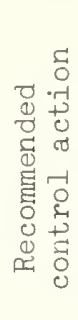 & 异 & 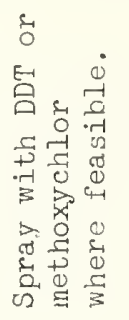 & & 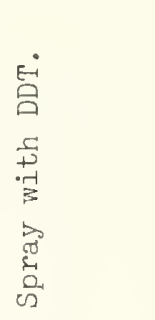 & 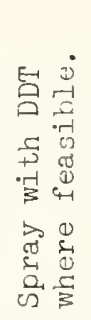 & $\begin{array}{l}\dot{0} \\
\stackrel{0}{0}\end{array}$ & 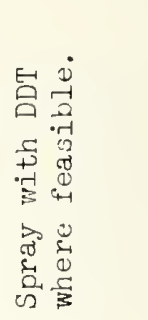 \\
\hline 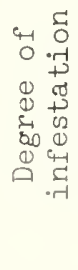 & 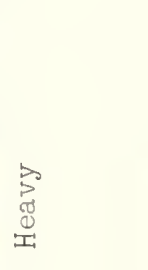 & 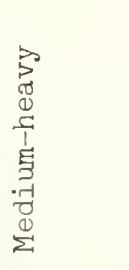 & 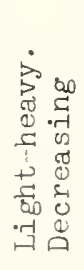 & 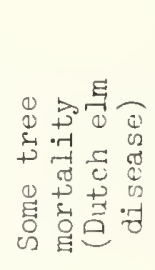 & 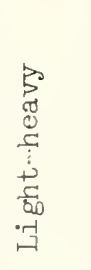 & 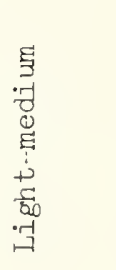 & 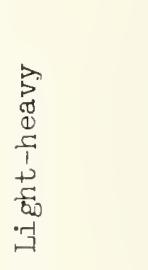 \\
\hline 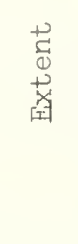 & 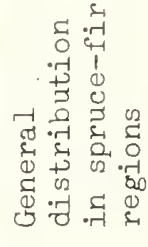 & 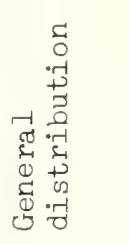 & 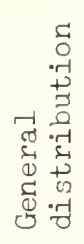 & 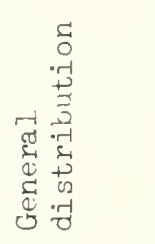 & 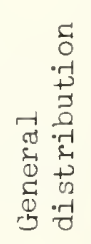 & 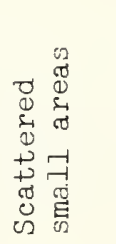 & 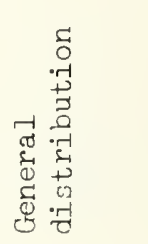 \\
\hline 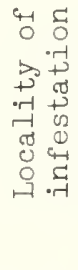 & 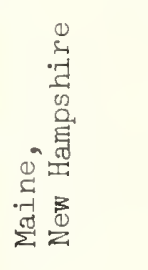 & 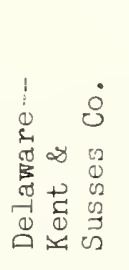 & 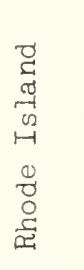 & 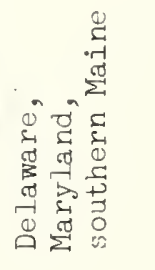 & 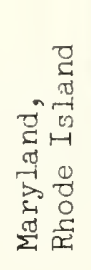 & 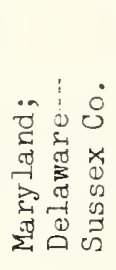 & 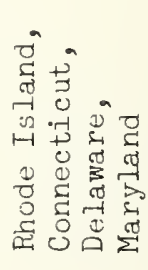 \\
\hline $\begin{array}{l}+ \\
\text { 落 } \\
\text { 足 }\end{array}$ & 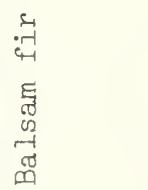 & $\begin{array}{l}02 \\
0 \\
0 \\
0 \\
0 \\
0 \\
0 \\
\frac{0}{11} \\
0\end{array}$ & & $\underset{\text { 吉 }}{\xi}$ & 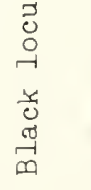 & 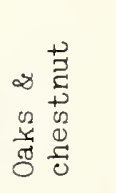 & 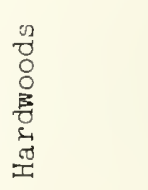 \\
\hline 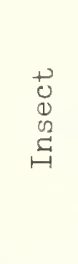 & 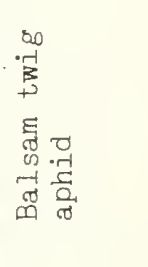 & 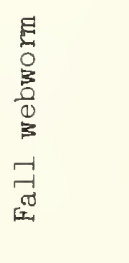 & & 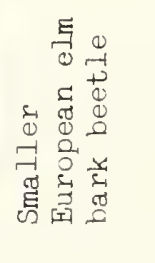 & 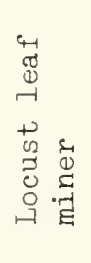 & 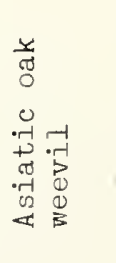 & 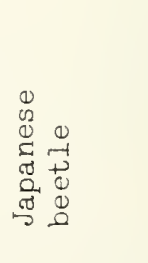 \\
\hline
\end{tabular}




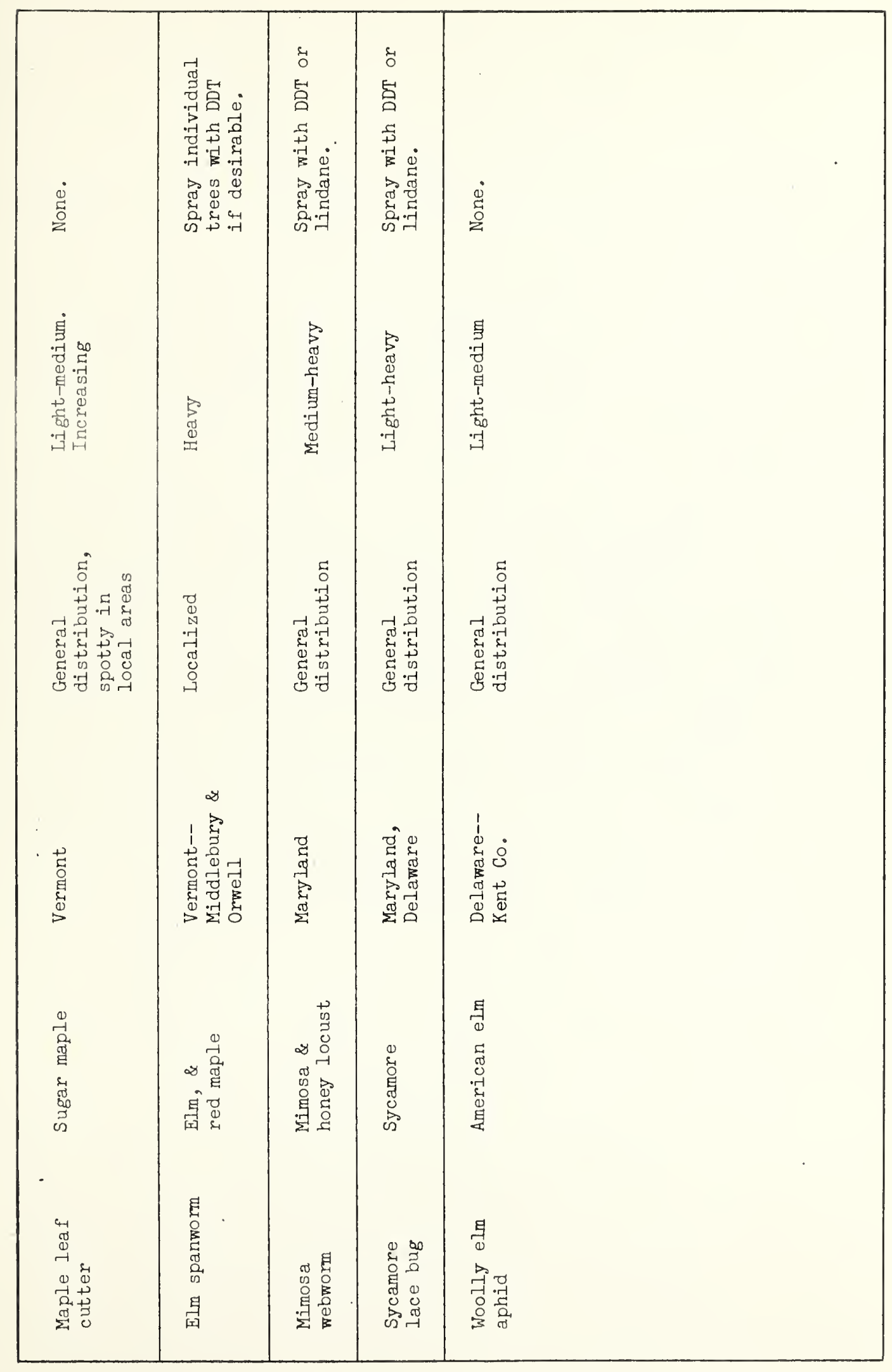


